\title{
PENINGKATAN KEAKTIFAN DAN HASIL BELAJAR EKONOMI DENGAN MODEL PEMBELAJARAN KOOPERATIF TIPE MAKE A MATCH PADA PESERTA DIDIK KELAS X IPS 3 MAN 2 BANTUL
}

\author{
Mas Indah Murdaningrum \\ MAN 2 Bantul \\ alkhalifimaninda@gmail.com
}

\begin{abstract}
Abstrak
Penelitian ini bertujuan meningkatkan keaktifan dan hasil belajar ekonomi peserta didik dengan Model Pembelajaran Kooperatif Tipe Make A Match di MAN 2 Bantul. Subjek penelitian adalah peserta didik kelas X IPS 3 MAN 2 Bantul berjumlah 29 orang. Teknik pengumpulan data menggunakan observasi dan tes. Teknik analisis data menggunakan deskriptif kuantitatif. Hasil penelitian menunjukkan bahwa pembelajaran dengan menggunakan model kooperatif tipe Make A Match dapat meningkatkan keaktifan dan hasil belajar peserta didik. Hal ini dibuktikan dengan peningkatan keaktifan belajar ekonomi pada siklus I, peserta didik yang mempunyai keaktifan belajar kategori minimal sedang sebesar $62,64 \%$, pada siklus II meningkat menjadi $77,58 \%$. Peningkatan hasil belajar peserta didik dilihat dari rerata kelas siklus I ke siklus II mengalami kenaikan. Peserta didik yang mengalami tuntas belajar pada siklus I sebesar 62,07\%, dan meningkat pada siklus II sebesar $86,21 \%$.
\end{abstract}

Kata Kunci: Hasil Belajar, Keaktifan, Make A Match, Model Pembelajaran

\begin{abstract}
This study aims to increase the students' activeness and economic learning outcomes with the Make A Match Type Cooperative Learning Model at MAN 2 Bantul. The research subjects were 29 students of class X IPS 3 MAN 2 Bantul. Data collection techniques using observation and tests. The data analysis technique used descriptive quantitative. The results showed that learning using the Make $A$ Match type cooperative model could increase the activeness and learning outcomes of students. This is evidenced by the increase in an economic learning activity in the first cycle, students who have a learning activity in the moderate category of at least $62.64 \%$, in the second cycle it increases to $77.58 \%$. The increase in student learning outcomes seen from the average class of cycle I to cycle II has increased. Students who have completed learning in the first cycle are $62.07 \%$ and increased in the second cycle by 86.21 .
\end{abstract}

Keywords: Activity, Learning Model, Learning Outcomes, Make A Match 


\section{PENDAHULUAN}

Pendidikan adalah suatu proses untuk membentuk karakter peserta didik agar menjadi pribadi yang baik. Menurut Undang-Undang Nomor 20 Tahun 2003, pendidikan adalah usaha sadar dan terencana untuk mewujudkan suasana belajar dan proses pembelajaran agar peserta didik secara aktif mengembangkan potensi dirinya untuk memiliki kekuatan spiritual keagamaan, pengendalian diri, kepribadian, kecerdasan, akhlak mulia, serta ketrampilan yang diperlukan dirinya, masyarakat, bangsa dan negara. Hidayat mengatakan pendidikan adalah usaha sadar dan terencana untuk memberikan bimbingan atau pertolongan dalam mengembangkan potensi jasmani dan rohani yang diberikan oleh orang dewasa kepada peserta didik untuk mencapai kedewasaanya serta mencapai tujuan agar peserta didik mampu melaksanakan tugas hidupnya secara mandiri (Hidayat \& Abdilah, 2019). Pendidikan juga diperlukan untuk membantu, membimbing, dan mengarahkan peserta didik dalam mengembangkan potensi yang ia miliki dan menjadikannya seorang manusia dewasa yang matang dan sempurna untuk mencapai tujuan hidup yang direncanakan. Melihat begitu pentingnya pendidikan dalam pembentukkan sumber daya manusia, maka peningkatan mutu pendidikan merupakan hal yang wajib dilakukan secara berkesinambungan.

MAN 2 Bantul merupakan salah satu madrasah negeri yang ada di Kabupaten Bantul Provinsi Yogyakarta. MAN 2 Bantul merasa harus berada di garda terdepan mewujudkan amanah masyarakat dan pemerintah kabupaten untuk menjadi institusi pendidikan yang maju, inklusif, dapat dipercaya dan ikut andil dalam pembangunan sumber daya manusia yang unggul, berdaya saing tinggi dalam bidang sains dan teknologi, mantab dalam Iman dan taqwa, berwawasan lingkungan dan peka terhadap globalisasi. Pembelajaran yang berkualitas adalah pembelajaran yang mengedepankan peran serta peserta didik dalam pembelajaran. Proses pembelajaran di sekolah sangat bergantung pada guru. Seorang pendidik atau guru harus mampu merancang strategi pembelajaran yang tepat. Kemampuan guru dalam merancang pembelajaran akan menentukan berhasil atau tidaknya proses pembelajaran di dalam kelas dalam mencapai tujuan pembelajaran yang diharapkan. Seorang guru harus mampu membuat peserta didik memiliki keinginan untuk belajar tentang materi yang akan disampaikan. Apabila hal ini dapat dilakukan oleh guru maka proses pembelajaran dapat berjalan dengan baik. Belajar merupakan proses yang di dalamnya terdapat suatu proses berfikir, menganalisis, mengingat dan mengambil kesimpulan dari apa yang dipelajari. Belajar dapat dijadikan sebagai proses perubahan lahir dan batin menuju kearah kemajuan atau perbaikan. Strategi pembelajaran yang diterapkan dalam proses pembelajaran di sekolah harus tepat dan efektif. Penentuan strategi pembelajaran dilakukan dengan melakukan pemilihan metode pembelajaran. Metode-metode pembelajaran yang digunakan dalam proses pembelajaran di dalam kelas dapat dilakukan secara variatif. Hal ini bertujuan untuk mencegah peserta didik mengalami kebosanan atau penurunan motivasi dalam mengikuti proses pembelajaran di dalam kelas. Pendekatan pembelajaran dengan berpusat pada peserta didik (student centered) dan metode pembelajaran kooperatif dapat meningkatkan keaktifan belajar peserta didik. Semakin tinggi aktivitas belajar peserta didik maka penyerapan materi yang diperoleh peserta didik semakin besar dan dapat meningkatkan hasil belajar yang dicapai. Dalam proses pembelajaran, penggunaan metode pembelajaran menjadi salah satu penunjang keberhasilan guru dalam mengajar. Penyampaian materi melalui metode pembelajaran yang monoton seperti ceramah belum mampu membangkitkan keaktifan belajar peserta didik. Metode ceramah baik 
untuk menyampaikan materi, namun sebaiknya tidak mendominasi dan terusmenerus digunakan dalam pembelajaran. Jika metode ceramah terus menerus digunakan peserta didik tidak memiliki kesempatan lebih untuk menggali dan membangun pengetahuan peserta didik sendiri. Keadaan tersebut yang menyebabkan peserta didik menjadi pasif dalam pembelajaran sehingga hasil tes juga menjadi rendah.

Berdasarkan hasil perolehan nilai dalam proses pembelajaran yang dilakukan pada semester 1 kelas X IPS MAN 2 Bantul tahun ajaran 2019/2020 masih banyak peserta didik yang mendapatkan nilai dibawah Kriteria Ketuntasan Minimal (KKM).

Tabel 1. Nilai Ulangan Harian Semester 1 Mata Pelajaran Ekonomi Tahun Pelajaran

\begin{tabular}{cccccc}
\multicolumn{5}{c}{$2019 / 2020$} \\
\hline Kelas & $\begin{array}{c}\text { Jumlah } \\
\text { Peserta } \\
\end{array}$ & \multicolumn{3}{c}{ Tuntas } & \multicolumn{3}{c}{ Belum Tuntas } \\
\cline { 3 - 6 } & didik & Jah & $\%$ & Jum & lah \\
\hline X IPS 1 & & & & & \\
UH1 & & 14 & 50,00 & 14 & 50,00 \\
UH2 & 28 & 10 & 35,71 & 18 & 64,29 \\
UH3 & & 12 & 42,86 & 16 & 57,14 \\
UH4 & & 13 & 46,43 & 15 & 53,57 \\
X IPS 3 & & & & & \\
UH1 & & 10 & 34,42 & 19 & 65,58 \\
UH2 & 29 & 14 & 48,28 & 15 & 51,72 \\
UH3 & & 12 & 41,38 & 17 & 58,62 \\
UH4 & & 13 & 44,83 & 16 & 55,17 \\
X IPS 3 & & & & & \\
UH1 & & 15 & 50,00 & 15 & 50,00 \\
UH2 & 30 & 14 & 46,67 & 16 & 53,33 \\
UH3 & & 9 & 30,00 & 21 & 70,00 \\
UH4 & & 19 & 63,33 & 11 & 36,67 \\
\hline
\end{tabular}

Hasil belajar pada dasarnya merupakan akibat dari suatu proses kegiatan belajar mengajar. Hal ini berarti, optimalnya hasil belajar peserta didik tergantung pada proses belajar dan proses mengajar guru. Hasil belajar dapat baik apabila pada pelaksanaan proses belajar mengajar sesuai dengan perencanaan pembelajaran yang tertuang dalam Rencana Pelaksanaan Pembelajaran (RPP). Hasil belajar merupakan hasil dari suatu interaksi tindak belajar dan tindak mengajar. Dari sisi guru, tindak mengajar diakhiri dengan proses evaluasi hasil belajar. Dari sisi peserta didik, hasil belajar merupakan berakhirnya penggal dan puncak proses belajar (Dimyati dan Mudjiono, 2015). Pencapaian hasil belajar peserta didik dalam pelajaran ekonomi diartikan sebagai pencapaian pengetahuan dan keterampilan di bidang ekonomi atau penguasaan materi ekonomi secara keseluruhan dalam kegiatan belajar mengajar ekonomi disekolah. Hasil belajar ekonomi merupakan hasil belajar yang telah dicapai pada mata pelajaran ekonomi yang ditunjukkan dengan nilai tes atau angka yang diberikan oleh guru ekonomi.

Cara untuk meningkatkan hasil belajar melalui penerapan berbagai model pembelajaran yang mengaktifkan dan mendorong kerjasama antar peserta didik, disamping itu penggunaan media pembelajaran bersama juga mendorong peningkatan partisipasi yang kondusif. Model pembelajaran kooperatif tipe MakeA Match menekankan pada permainan dan kerjasama. Kelebihan dari Model pembelajaran Koperatif tipe Make a Match adalah sebagai berikut: (1) Dapat meningkatkan aktivitas belajar peserta didik, baik secara kognitif maupun fisik, (2) Karena ada unsur permainan, metode ini menyenangkan, (3) Meningkatkan pemahaman peserta didik terhadap materi yang dipelajari dan dapat meningkatkan motivasi belajar peserta didik, (4) Efektif sebagai sarana melatih keberanian peserta didik untuk tampil presentasi, (5) Efektif melatih kedisiplinan peserta didik menghargai waktu untuk belajar (Huda, 2015). Dalam pembelajaran kooperatif peserta didik dibagi atas kelompok-kelompok. Pembagian kelompok ini dimaksudkan agar setiap peserta didik dapat berkolaborasi dengan teman, lingkungan, guru maupun semua pihak yang terkait dalam proses pembelajaran. Dengan demikian diharapkan tujuan dari proses pembelajaran dapat tercapai karena setiap peserta didik menjadi lebih aktif, memiliki motivasi untuk belajar serta memiliki kesiapan dalam mengikuti proses kegiatan belajar mengajar (KBM) di sekolah. Model pembelajaran kooperatif tipe Make A Match diharapkan mampu mengatasi kelemahankelemahan yang melekat pada pembelajaran klasikal. 
Berdasarkan hasil pengamatan yang dilakukan di kelas X IPS 2 MAN 2 Bantul tahun ajaran 2019/2021, diperoleh bahwa peserta didik cenderung pasif dalam proses pembelajaran, keaktifan peserta didikan hampir tidak berkembang. Ketergantungan peserta didik masih tinggi terhadap kehadiran guru, akibatnya proses belajar berlangsung satu arah dan peserta didik masih ragu dan takut untuk menyampaikan pendapat maupun pertanyaan kepada guru. Kenyataan ini menyebabkan rendahnya hasil belajar peserta didik. Hal ini dapat dilihat masih ada peserta didik yang bermain sendiri, berbicara dengan teman saat guru menjelaskan, mengantuk, membuat gaduh di dalam kelas, melihat sesuatu di luar kelas, izin keluar masuk kelas.

Atas dasar kondisi tersebut, maka perlu dilakukan penelitian tentang Peningkatan Keaktifan dan Hasil Belajar Ekonomi Materi Badan Usaha dengan Model Pembelajaran Kooperatif Tipe Make A Match pada Peserta Didik Kelas X IPS 3 MAN 2 Bantul Semester Genap Tahun Pelajaran 2019/2020.

Rumusan masalah dari penelitian ini adalah bagaimana peningkatan keaktifan dan hasil belajar ekonomi peserta didikkelas $\mathrm{X}$ IPS 3 melalui Model Pembelajaran Kooperatif tipe Make A Match di MAN 2 Bantul tahun ajaran 2019/2020?. Dengan dasarpermasalahan tersebut, peneliti melakukan penelitian tindakan kelas yang bertujuan untuk mengetahui peningkatan keaktifandan hasil belajar ekonomi pada peserta didik kelas X IPS 3 MAN 2 Bantul tahun ajaran 2019/2020.

Manfaat teoritis penelitian ini diharapkan dapat menambah keragaman ilmu pengetahuan tentang keaktifan dan hasil belajar ekonomi peserta didik melalui model pembelajaran kooperatif tipe Make A Match. Selain itu, penelitian ini dapat menjadi acuan penelitian sejenis berikutnya. Manfaat praktis bagi peserta didik adalah dengan penerapan model pembelajaran kooperatif tipe Make A Match, diharapkan dapat meningkatkan keaktifan dan hasil belajar peserta didik saat mempelajari mata pelajaran ekonomi. Bagi guru diharapkan hasil penelitian ini dapat menjadikan sumber untuk meningkatkan kemampuan guru untuk berkreasi dan berinovasi pada pembelajaran sehingga lebih efektif dan efisien menjalankan peranannya sebagai fasilitator dan mediator. Bagi sekolah hasil penelitian ini dapat menjadi bahan masukan dalam rangka mengefektifkan pembinaan dan pengelolaan sumber-sumber belajar.

\section{KAJIAN PUSTAKA}

\section{A. Keaktifan}

Strategi pembelajaran aktif dalam proses pembelajaran adalah peserta didik diharapkan aktif terlibat dalam kegiatan pembelajaran untuk berpikir, berinteraksi, berbuat untuk mencoba, menemukan konsep baru atau menghasilkan suatu karya (Uno dan Mohamad, 2013). Belajar aktif merupakan salah satu cara untuk mengikat informasi yang baru kemudian mengingatnya. Dengan belajar aktif peserta didik diajak untuk turut serta dalam semua proses pembelajaran baik secara fisik maupun mental. Belajar aktif adalah pembelajaran yang memposisikan peserta didik sebagai subjek dalam pembelajaran, sehingga memberikan konsekuensi keterlibatan peserta didik secara penuh mulai dari perencanaan pembelajaran, proses pembelajaran sampai pada evaluasi pembelajaran (Rusman, 2018). Ketika peserta didik pasif atau hanya menerima materi dari pengajar maka akan ada kecenderungan untuk cepat melupakan materi yang telah diberikan. Kurang aktifnya peserta didik dalam proses pembelajaran menyebabkan tingkat pemahaman peserta didik terhadap materi pelajaran rendah. Dengan belajar secara aktif peserta didik diajak untuk turut serta dalam semua proses pembelajaran baik secara mental maupun fisik sehingga suasana proses pembelajaran menjadi lebih menyenangkan dan hasil belajar dapat ditingkatkan. Dalam meningkatkan keaktifan belajar peserta didik, guru harus melakukan upaya upaya untuk 
memancing keaktifan belajar peserta didik. Upaya tersebut bisa berupa memberikan pertanyaan, memberikan motivasi, memberi penghargaan, maupun memberikan tugas kepada peserta didik. Rangkaian kegiatan pembelajaran yang dilakukan untuk menumbuhkan keaktifan belajar peserta didik, antara lain: 1) Mengemukakan berbagai alternatif tujuan pembelajaran yang harus dicapai sebelum kegiatan pembelajaran dimulai, 2) Menyusun tugas-tugas belajar bersama peserta didik, 3) Memberi informasi tentang kegiatan pembelajaran yang harus dilakukan, 4) Memberikan bantuan dan pelayanan kepada peserta didik yang memerlukan, Memberikan motivasi, mendorong peserta didik untuk belajar, membimbing, dan lain sebagainya melalui pengajuan pertanyaanpertanyaan, 6) Membantu peserta didik dalam menarik suatu kesimpulan kegiatan pembelajaran (Sanjaya, 2013).

Dari pendapat beberapa ahli di atas, upaya meningkatkan keaktifan belajar peserta didik dapat dilakukan dengan cara menjelaskan tujuan pembelajaran yang harus dicapai sebelum kegiatan pembelajaran dimulai, memberi informasi tentang kegiatan pembelajaran yang harus dilakukan, memberikan motivasi, mendorong peserta didik untuk belajar, membimbing dan lain sebagainya melalui pengajuan pertanyaan-pertanyaan, memberikan bantuan dan pelayanan kepada peserta didik yang memerlukan, dan membantu peserta didik dalam menarik suatu kesimpulan kegiatan pembelajaran.

\section{B. Hasil Belajar}

Sebagai salah satu patokan untuk mengukur keberhasilan proses pembelajaran, hasil belajar merefleksikan hasil dari proses pembelajaran yang menunjukkan sejauh mana peserta didik, guru, proses pembelajaran, dan lembaga pendidikan telah mencapai tujuan pendidikan yang telah ditentukan (Kpolovie et al., 2014). Hasil belajar merupakan pengalaman yang diperoleh peserta didik meliputi ranah kognitif, afektif, dan psikomotorik. Belajar bukan hanya penguasaan konsep teori mata pelajaran saja, tetapi juga penguasaan kebiasaan, persepsi, kesenangan, jenis-jenis keterampilan, cita-cita, keinginan, minat-bakat, penyesuaian sosial dan harapan (Rusman, 2018). Hasil belajar merupakan dasar untuk mengukur dan melaporkan prestasi akademik dari peserta didik, serta merupakan kunci untuk mengembangkan desain pembelajaran selanjutnya yang lebih efektif yang memiliki keselarasan antara apa yang akan dipelajari peserta didik dan bagaimana mereka akan dinilai (Hamdan \& Khader, 2014). Berdasarkan definisi diatas, dapat disimpulkan bahwa hasil belajar merupakan hasil dari penyelesaian proses pembelajaran, dimana lewat pembelajaran peserta didik dapat mengetahui, mengerti, dan dapat menerapkan apa yang dipelajarinya yang dapat diukur menggunakan nilai hasil tes. Tes yang digunakan berupa tes tertulis dengan bentuk soal pilihan ganda.

\section{Model pembelajaran kooperatif tipe Make A Match}

Model pembelajaran kooperatif merupakan model pembelajaran yang menekankan peserta didik untuk aktif dalam proses pembelajaran. Model ini merupakan suatu bentuk pembelajaran dengan cara peserta didik belajar dan bekerja dalam kelompok kelompok kecil secara kolaboratif. Model pembelajaran ini dapat membantu peserta didik dalam mengembangkan keterampilan intelektual, sosial, dan menumbuhkan sikap toleransi terhadap perbedaan pendapat. Pembelajaran kooperatif merupakan bentuk pembelajaran dimana peserta didik belajar dan bekerja dalam kelompok kecil secara kolaboratif terdiri dari empat sampai enam orang dan struktur kelompok bersifat heterogen (Rusman, 2018).

Model pembelajaran Kooperatif tipe Make A Match merupakan salah satu jenis dari model pembelajaran kooperatif, yakni bentuk pembelajaran 
dengan cara peserta didik belajar dan bekerja dalam kelompok-kelompok kecil secara kolaboratif yang anggotanya terdiri dari empat sampai enam orang dengan struktur kelompok yang bersifat heterogen (Rusman, 2018).

\section{Langkah-langkah}

Model pembelajaran Kooperatif tipe Make $A$ Match menurut Huda adalah sebagai berikut : a) Guru menyampaikan materi atau memberi tugas kepada peserta didik untuk mempelajari materi di rumah. b) Peserta didik dibagi ke dalam 2 kelompok, misalnya kelompok A dan kelompok B. Kedua kelompok diminta untuk berhadap-hadapan. c) Guru membagikan kartu pertanyaan kepada kelompok A dan kartu jawaban ke kelompok B. d) Guru menyampaikan kepada peserta didik bahwa mereka harus mencari/mencocokan kartu yang dipegang dengan kartu kelompok lain. Guru juga perlu menyampaikan batasan maksimum waktu yang ia berikan kepada mereka. e) Guru meminta semua anggota kelompok A untuk mencari pasangannya di kelompok B. Jika mereka sudah menemukan pasangannya masingmasing, guru meminta mereka melaporkan diri kepadanya. Guru mencatat mereka pada kertas yang telah disediakan. f) Jika waktu sudah habis, peserta didik yang belum menemukan pasangan diminta untuk berkumpul sendiri. g) Guru memanggil satu pasangan untuk presentasi. Pasangan lain dan peserta didik yang tidak mendapatkan pasangan memperhatikan dan memberikan tanggapan apakah pasangan itu cocok atau tidak. h) Terakhir guru memberikan konfirmasi tentang kebenaran dan kecocokan pertanyaan dan jawaban dari pasangan yang memberikan presentasi. i) Guru memanggil pasangan berikutnya, begitu seterusnya sampai seluruh pasangan melakukan presentasi (h. 2015). Menurut Rusman langkah-langkah pembelajaran dengan model pembelajaran kooperatif tipe Make a Match adalah sebagai berikut: a) Guru menyiapkan beberapa kartu yang berisi beberapa konsep/topik yang cocok untuk sesi review (satu sisi kartu berupa kartu soal dan sisi sebaliknya berupa kartu jawaban). b) Setiap peserta didik mendapat satu kartu dan memikirkan jawaban atau soal dari kartu yang dipegang. c) Peserta didik mencari pasangan yang mempunyai kartu yang cocok dengan kartunya (kartu soal/jawaban). d) Peserta didik yang dapat mencocokkan kartunya sebelum batas waktu diberi poin. e) Setelah satu babak, kartu dikocok lagi agar tiap peserta didik mendapat kartu yang berbeda dari sebelumnya, demikian seterusnya. f) Kesimpulan, (Rusman, 2011). Berdasarkan pendapat-pendapat tersebut, dapat disimpulkan langkahlangkah model pembelajaran kooperatif tipe Make a Match adalah a) Guru menyampaikan materi atau memberi tugas kepada peserta didik untuk mempelajari materi di rumah. b) Peserta didik dibagi ke dalam dua kelompok besar yang heterogen, yaitu kelompok pertanyaan dan kelompok jawaban. c) Guru membagikan satu buah kartu kepada masing-masing peserta didik secara acak. Kartu pertanyaan diberikan kepada kelompok pertanyaan dan kartu jawaban diberikan kepada kelompok jawaban. d) Peserta didik memikirkan pasangan pertanyaan atau jawaban dari kartu yang diperolehnya. e) Guru menginstruksikan peserta didik untuk mencari pasangan kartu yang diperoleh dalam waktu yang disepakati. f) Peserta didik mencari pasangan kartu yang cocok dengan kartu yang diperolehnya. g) Guru memberikan tanda saat waktu mencari pasangan kartu telah habis. h) Guru mencatat nama peserta didik yang telah menemukan pasangan sebelum waktu habis. i) Guru memanggil setiap pasangan untuk melakukan presentasi. j) Guru bersama peserta didik memberikan konfirmasi tentang kebenaran dan kecocokan pertanyaan dan jawaban dari pasangann yang memberikan presentasi. k) Guru memanggil pasangan berikutnya sampai semua pasangan melakukan presentasi. l) Guru bersama peserta didik membuat kesimpulan pembelajaran yang telah dilakukan. 
Beberapa penelitian relevan sudah dilakukan di antaranya oleh Maharani dan Kristin terhadap siswa kelas V SD Negeri Jati Jajar 02c yang membuktikan bahwa penerapan metode pembelajaran kooperatif tipe Make A Match dapat meningkatkan hasil belajar dan keaktifan siswa dan lebih efektif jika dibandingkan dengan metode pembelajaran konvensional (Maharani \& Kristin, 2017). Berdasarkan eksperimen yang dilakukan oleh Pratiwi disimpulkan bahwa terdapat pengaruh positif pada metode pembelajaran "Make A Match" terhadap hasil belajar IPA sehingga dapat dijadikan sebagai metode pembelajaran alternatif, Cara-cara dalam metode "Make A Match" bertujuan menumbuhkan keaktifan siswa dalam pembelajaran dengan suasana yang menyenangkan serta memupuk kerjasama siswa dalam menjawab pertanyaan bersamasama.(Pratiwi, 2018). Penelitian yang dilakukan Syamsur, Lasmini dan Rahmi menyimpulkan bahwa penerapan Model Pembelajaran Kooperatif tipe Make A Match dapat meningkatkan hasil belajar (Samsur, 2018), (Lasmini, 2017), dan (Putri Z et al., 2017). Berdasarkan hasil penelitian Putri, disarankan bagi guru sosial untuk mencoba menggunakan model Make A Match dengan media kartu gambar di kelas IV sampai meningkatkan hasil belajar siswa (Putri, 2018).

\section{METODE PENELITIAN}

\section{Metode Penelitian}

Penelitian ini merupakan Penelitian Tindakan Kelas (PTK), yang terdiri dari dua siklus penelitian, masing-masing siklus terdiri dari tiga kali pertemuan, setiap siklus dalam proses pengkajian berdaur 4 tahap, yaitu merencanakan, melakukan tindakan, mengamati (observasi), dan refleksi.

\section{Setting Penelitian}

Penelitian ini dilaksanakan pada bulan Januari sampai dengan Bulan Mei 2020 di Kelas X IPS 3 MAN 2 Bantul Tahun Pelajaran 2019/2020.

\section{Subjek dan Objek Penelitian}

Subjek PTK ini adalah 29 peserta didik Kelas X IPS 3 MAN 2 Bantul Tahun Pelajaran 2019/2020. Objek penelitian adalah peserta didik Kelas X IPS 3 MAN 2 Bantul yang mengikuti pembelajaran ekonomi, guru mata pelajaran ekonomi yang mengajarkan materi BUMN dan BUMD, model pembelajaran kooperatif tipe Make a Match.

\section{Teknik Pengumpulan Data}

Teknik pengumpulan data dalam penelitian ini menggunakan observasi dan tes. Observasi digunakan untuk memperoleh data tentang proses pelaksanaan tindakan kegiatan belajar mengajar yang menggunakan model pembelajaran kooperatif tipe Make $A$ Match. Pelaksanaan dibantu oleh teman sejawat dengan maksud agar proses pembelajaran bisa direkam sedetail mungkin dari aspek langkah-langkah pembelajaran, perilaku guru dan peserta didik. Untuk melakukan observasi peneliti menggunakan lembar observasi untuk mengetahui kegiatan guru dan lembar observasi untuk mengetahui aktivitas peserta didik. Tes digunakan untuk mengukur hasil belajar peserta didik khususnya aspek kognitif. Peneliti menggunakan post test pada setiap siklus untuk mengetahui peningkatan hasil belajar ekonomi. Hasil post test pada siklus kedua akan dibandingkan dengan hasil post test siklus pertama untuk mengetahui ada tidaknya peningkatan hasil belajar peserta didik. Tes yang digunakan adalah berupa tes tertulis bentuk soal pilihan ganda.

\section{Teknik Analisis Data}

Analisis butir soal yang digunakan ada dua, yakni analisis tingkat kesukaran soal dan analisis daya pembeda. Analisis tingkat kesukaran soal digunakan untuk mengkaji soal-soal tes dari segi kesulitannya sehingga dapat diperoleh soal-soal mana yang termasuk mudah, sedang, dan sukar. Sedangkan analisis daya pembeda digunakan untuk mengkaji soal-soal tes dari segi kesanggupan tes tersebut dalam 
membedakan peserta didik yang termasuk ke dalam kategori lemah atau rendah dan kategori kuat atau tinggi prestasinya (Sudjana, 2017). Dalam penelitian ini digunakan aplikasi Anbuso (Analisis Butir Soal) untuk mengetahui kualitas tes yang digunakan. Anbuso ini dapat menganalisis butir soal objektif maupun uraian dengan mengetahui daya pembeda, tingkat kesukaran, dan alternatif jawaban tidak efektif untuk soal objektif. Hasil dari analisis ini berbentuk laporan ketuntasan peserta didik. Penelitian ini menggunakan teknik analisis data deskriptif kuantitatif. Data yang diperoleh dan dianalisis pada penelitian ini adalah data kuantitatif dari hasil observasi keaktifan belajar dan hasil belajar peserta didik mata pelajaran ekonomi kelas X IPS 3 MAN 2 Bantul. Penelitian tindakan kelas ini dikatakan berhasil apabila terjadi peningkatan keaktifan dan hasil belajar peserta didik yang dilihat dari nilai post-test dari siklus satu dan siklus dua, pada mata pelajaran ekonomi dengan diterapkannya Model Pembelajaran Kooperatif Tipe Make A Match. Tindakan dikatakan berhasil jika minimal $75 \%$ peserta didik aktif dan mencapai KKM, dimana telah ditetapkan KKM sebesar 70.

\section{HASIL PENELITIAN DAN PEMBAHASAN}

\section{Hasil Penelitian}

Penelitian Tindakan Kelas yang telah dilakukan oleh penulis sebagai peneliti sejak mulai siklus I hingga siklus kedua pada bulan Januari hingga April 2020, dibantu oleh seorang guru Ekonomi bernama Fitria Endang Susana S.Pd, sebagai observer dan berfungsi sebagai teman sejawat dalam berdiskusi pada tahap refleksi.

\section{Siklus I}

Rencana tindakan pada siklus I untuk memperbaiki keaktifan dan hasil belajar peserta didik, sebelum melakukan tindakan guru menyiapkan berbagai hal agar proses pembelajaran dengan model pembelajaran kooperatif tipe Make $A$ Match dapat berjalan dengan maksimal. Pada siklus pertama ini Rencana
Pelaksanaan Pembelajaran (RPP) dibuat untuk tiga kali pertemuan. RPP dikembangkan dengan menggunakan model pembelajaran kooperatif tipe Make A Match sesuai dengan langkahlangkah yang dibahas dalam kajian teori. Langkah-langkah yang peneliti lakukan adalah: 1) Menyiapkan perangkat pembelajaran meliputi analisis keterkaitan KI, KD dengan IPK, Silabus, RPP, KKM, beserta alat dan bahan yang menunjang dalam kegiatan pembelajaran. 2) Mempersiapkan materi dan media pembelajaran berupa powerpoint materi BUMN dan BUMD sesuai dengan tujuan pembelajaran dan IPK pada RPP. 3) Merancang soal ulangan harian beserta kisi-kisi dan kunci jawaban untuk mengetahui hasil belajar peserta didik. 4)Merancang lembar observasi untuk mengetahui keaktifan dan aktivitas belajar peserta didik. 5) Membuat dua jenis kartu yaitu kartu soal dan jawaban yang jumlahnya disesuaikan dengan jumlah peserta didik. 6)Membagi peserta didik menjadi dua kelompok besar, dimana kelompok pertama akan mendapatkan kartu pertanyaan dan kelompok kedua mendapatkan kartu jawaban. 7)Mempersiapkan alat dokumentasi berupa kamera. 8) Peserta didik mencari pasangan pada setiap kartu yang dipegangnya dengan durasi telah ditetapkan oleh guru. 9)Setelah waktu yang telah ditetapkan habis, maka guru akan mengoreksi hasil pekerjaan peserta didik.

Hasil observasi yang dilakukan bersama oleh observer (teman sejawat), dengan menggunakan lembar observasi dalam tiga kali pertemuan, yakni pertemuan pertama hari Senin, 13 Januari 2020, pertemuan kedua pada hari Kamis, 16 Januari 2020, pertemuan ketiga pada hari Kamis, 20 Januari 2020, ditemukan bahwa proses pembelajaran berlangsung sebagai berikut:

\section{Pertemuan Pertama.}

Pelaksanaan tindakan pada siklus I pertemuan I dilaksanakan pada hari Senin tanggal 13 Januari 2020 mulai jam kedua sampai dengan jam ke-4 dengan 
jumlah peserta didik yang hadir sebanyak 29 orang. Pada kegiatan pendahuluan guru telah menjelaskan cara pelaksanaan pembelajaran kooperatif tipe Make A Match kepada peserta didik, namun peserta didik masih belum terbiasa melaksanakan pembelajaran kooperatif tipe Make A Match. Pada saat guru menyampaikan materi, beberapa peserta didik kurang memperhatikan dan hanya sedikit peserta didik yang bertanya atau mengemukakan pendapatnya, bahkan harus ditunjuk terlebih dahulu. Ada peserta didik yang masih mengobrol dengan teman sebelahnya, bahkan ada yang masih tidur-tiduran saat pembelajaran. Pada saat mencari pasangan kartu, suasana kelas menjadi gaduh dan tidak kondusif, karena peserta didik berbaur saling mencari pasangan kartu yang diperolehnya. Namun ada juga peserta didik yang hanya pasif menunggu, ada peserta didik lain yang bertanya dan ada yang masih terlihat bingung. Saat pelaksanaan presentasi berpasangan, masih banyak peserta didik yang tidak memperhatikan presentasi. Ada yang mengobrol, bermain, atau melamun. Peserta didik yang presentasi di depan kelas, juga ada yang tidak ikut menyampaikan presentasi dan hanya mengandalkan pasangannya. Pada saat guru melakukan tanya jawab di akhir pertemuan, peserta didik masih perlu dibimbing oleh guru agar berani untuk mengemukakan pendapatnya.

\section{Pertemuan kedua}

Pertemuan kedua siklus I dilaksanakan pada hari Kamis, 16 Januari 2020 jam 10.15 sampai jam 11.00. Pada pertemuan kedua siklus I, guru semakin baik dalam menerapkan pembelajaran kooperatif Make A Match. Saat pelaksanaan pembelajaran, sudah semakin banyak peserta didik yang memperhatikan dan mencatat materi, karena mereka menyadari materi tersebut akan berguna pada saat mencari pasangan kartu dan evaluasi. Beberapa peserta didik juga semakin aktif bertanya jika ada yang belum jelas mengenai materi pembelajaran. Namun pada saat diberi kesempatan untuk menyampaikan pendapat atau menjawab pertanyaan teman, peserta didik masih terlihat enggan untuk langsung menyampaikan. Pada saat pencarian pasangan kartu, suasana kelas menjadi gaduh karena peserta didik berbaur mencari pasangan kartu. Namun ada juga peserta didik yang masih pasif dan hanya menunggu. Dari pencarian pasangan kartu, dua peserta didik masih belum mendapatkan pasangan. Pada saat presentasi pasangan, perhatian peserta didik sudah mulai terfokus pada pasangan yang presentasi walaupun masih ada beberapa peserta didik yang mengobrol atau jalan-jalan.

Pelaksanaan pembelajaran pada pertemuan kedua siklus I, diperoleh data bahwa peserta didik sudah memahami langkah-langkah dalam pembelajaran kooperatif tipe Make A Match sehingga pembelajaran berjalan lebih baik dari pertemuan sebelumnya. Berikut ini merupakan refleksi dari pelaksanaan tindakan pada pertemuan kedua siklus I yaitu: 1) Masih banyak peserta didik yang tidak memperhatikan pada saat guru menyampaikan materi dan saat presentasi pasangan. 2) Masih banyak peserta didik yang tidak mencatat materi penting. 3) Masih ada beberapa peserta didik yang pasif pada saat permainan mencari pasangan kartu. 4) Peserta didik masih perlu bimbingan guru untuk bertanya atau mengemukakan pendapat. 5) Masih ada beberapa peserta didik yang hanya mengandalkan pasangannya yang lebih pandai pada saat presentasi. 6) Ada peserta didik yang masih suka mengobrol dengan teman, bermain, bahkan tidur-tiduran.

\section{Pertemuan ketiga}

Pertemuan ketiga siklus I dilaksanakan pada Hari Senin, 20 Januari 2020 jam 07.45 WIB. Pada pertemuan ketiga siklus I, guru semakin baik dalam menerapkan pembelajaran kooperatif Make A Match. Saat pelaksanaan pembelajaran, sudah semakin banyak peserta didik yang memperhatikan dan mencatat materi. 
Beberapa peserta didik juga semakin aktif bertanya jika ada yang belum jelas mengenai materi pembelajaran. Namun pada saat diberi kesempatan untuk menyampaikan pendapat atau menjawab pertanyaan teman, peserta didik masih terlihat enggan untuk langsung menyampaikan. Pada saat pencarian pasangan kartu, suasana kelas menjadi gaduh karena peserta didik berbaur mencari pasangan kartu. Namun ada juga peserta didik yang masih pasif dan hanya menunggu. Dari pencarian pasangan kartu satu peserta didik masih belum mendapatkan pasangan. Pada saat presentasi pasangan, perhatian peserta didik sudah mulai terfokus pada pasangan yang presentasi walaupun masih ada beberapa peserta didik yang mengobrol.

Pada pelaksanaan pembelajaran pada pertemuan ketiga siklus I, diperoleh data bahwa peserta didik sudah memahami langkah-langkah dalam pembelajaran kooperatif tipe Make A Match sehingga pembelajaran berjalan lebih baik dari pertemuan sebelumnya. Berikut ini merupakan refleksi dari pelaksanaan tindakan pada pertemuan ketiga siklus I yaitu: 1) Beberapa peserta didik yang tidak memperhatikan pada saat guru menyampaikan materi dan saat presentasi pasangan. 2) Masih cukup banyak peserta didik yang tidak mencatat materi penting. 3) Masih ada beberapa peserta didik yang pasif pada saat permainan mencari pasangan kartu. 4) Peserta didik masih perlu bimbingan guru untuk bertanya atau mengemukakan pendapat. 5) Masih ada beberapa peserta didik yang hanya mengandalkan pasangannya yang lebih pandai pada saat presentasi. 6) Ada peserta didik yang masih suka mengobrol dengan teman, bermain, bahkan tidur-tiduran. 7) banyak peserta didik yang saling bekerjasama dan membuka catatan secara diam-dian pada saat ulangan harian berlangsung.

Menurut hasil observasi mengenai keaktifan peserta didik menggunakan pembelajaran kooperatif tipe Make $A$ Match pada siklus I, belum semua peserta didik melakukan keaktifan seperti pada aspek yang diamati dan mencapai indikator keberhasilan.

Tabel 2. Rekapitulasi Data Keaktifan Peserta didik pada Siklus I

\begin{tabular}{llcccc}
\hline No & \multicolumn{1}{c}{$\begin{array}{c}\text { Aspek yang } \\
\text { diamati }\end{array}$} & \multicolumn{4}{c}{ Siklus I } \\
\cline { 2 - 6 } 1 & $\begin{array}{l}\text { Memperhatikan } \\
\text { penjelasan guru }\end{array}$ & $70,69 \%$ & $75,86 \%$ & $77,58 \%$ & $74,71 \%$ \\
2 & $\begin{array}{l}\text { Mencatat materi } \\
\text { pelajaran }\end{array}$ & $70,69 \%$ & $81,03 \%$ & $84,48 \%$ & $78,73 \%$ \\
3 & $\begin{array}{l}\text { Mengajukan } \\
\text { pertanyaan } \\
\text { Menjawab } \\
\text { pertanyaan } \\
\text { atau memberi } \\
\text { tanggapan }\end{array}$ & $29,31 \%$ & $34,48 \%$ & $46,55 \%$ & $36,78 \%$ \\
& $\begin{array}{l}\text { Berinteraksi } \\
\text { dengan } \\
\text { peserta didik lain } \\
\text { saat mencari } \\
\text { pasangan kartu }\end{array}$ & $74,14 \%$ & $32,76 \%$ & $39,66 \%$ & $34,49 \%$ \\
$\begin{array}{l}\text { Menjelaskan } \\
\text { materi pada saat } \\
\text { presentasi }\end{array}$ & $43,10 \%$ & $46,55 \%$ & $51,72 \%$ & $47,12 \%$ \\
& $\begin{array}{l}\text { Memperhatikan } \\
\text { penjelasan peserta } \\
\text { didik lain } \\
\text { Saat presentasi } \\
\text { Rata-rata }\end{array}$ & $34,48 \%$ & $37,93 \%$ & $44,83 \%$ & $39,08 \%$ \\
\hline
\end{tabular}

Dari hasil observasi, nilai rata-rata keaktifan peserta didik pada siklus I yaitu pertemuan pertama 50,49\%, pertemuan kedua $55,91 \%$ dan pertemuan ke tiga 61,33\%. Peningkatan keaktifan peserta didik dari pertemuan pertama kepertemuan kedua siklus I yaitu sebesar $5,42 \%$ dari pertemuan kedua ke pertemuan tiga naik sebesar 55,42\%. Rata-rata keaktifan peserta didik disiklus I sebesar 55,91\%. Berikut ini rekapitulasi persentase keaktifan peserta didik pada siklus I.

Tabel 3. Indikator Keberhasilan Keaktifan Belajar Peserta Didik Siklus I

\begin{tabular}{|c|c|c|c|c|c|}
\hline \multirow[b]{2}{*}{ No } & \multirow{2}{*}{$\begin{array}{c}\text { Kategori } \\
\text { Keaktifan }\end{array}$} & \multicolumn{3}{|c|}{ Siklus I } & \multirow{2}{*}{$\begin{array}{c}\text { Rata-rata } \\
(\%) \\
\text { Siklus I } \\
\end{array}$} \\
\hline & & $\begin{array}{l}\text { Pertemu } \\
\text { an } 1\end{array}$ & $\begin{array}{c}\text { Pertemu } \\
\text { an } 2 \\
\end{array}$ & $\begin{array}{l}\text { Pertemu } \\
\text { an } 3\end{array}$ & \\
\hline 1 & Tinggi & $\begin{array}{c}6 \\
(20,69 \%)\end{array}$ & $\begin{array}{c}7,5 \\
(25,86 \%)\end{array}$ & $\begin{array}{c}10 \\
(34,48 \%)\end{array}$ & $27,01 \%$ \\
\hline 2 & Sedang & $\begin{array}{c}10,5 \\
(36,21 \%)\end{array}$ & $\begin{array}{c}10,5 \\
(36,21)\end{array}$ & $\begin{array}{c}10 \\
(34,48 \%)\end{array}$ & $35,63 \%$ \\
\hline 3 & Rendah & $\begin{array}{c}11,5 \\
(43,10 \%)\end{array}$ & $\begin{array}{c}11 \\
(37,93 \%)\end{array}$ & $\begin{array}{c}9 \\
(31,04 \%)\end{array}$ & $37,36 \%$ \\
\hline
\end{tabular}

Pada siklus pertama ini kategori keaktifan rendah sudah berkurang banyak tinggal sebesar 37,36\%, kategori sedang mencapai $35,63 \%$ dan kategori tinggi sebesar 27,01\%. Dengan demikian 
pada siklus I ini keaktifan belajar peserta didik mengalami peningkatan dari pertemuan pertama sampai pertemuan ketiga, tetapi penelitian ini belum dikatakan berhasil, karena indikator yang ditetapkan adalah jika persentase peserta didik yang keaktifannya dengan kategori sedang dan tinggi minimal mencapai $75 \%$, padahal di siklus I ini kategori rendah masih 37,36\%, sehingga penelitian ini dilanjutkan pada siklus II.

Pada akhir pertemuan ketiga dilaksanakan post-test untuk mengukur pencapaian hasil belajar peserta didik pada materi KD 3.7 Badan Usaha Milik Negara (BUMN) dan Badan Usaha Milik Daerah (BUMD) dan KD 4.7 Menyajikan peran, fungsi dan kegiatan badan usaha dalam perekonomian Indonesia. Indikator keberhasilan dari penelitian ini adalah, PTK dikatakan sudah berhasil jika persentase peserta didik yang nilai hasil belajarnya sudah tuntas mencapai minimal $75 \%$.

Tabel 4. Daftar Nilai Peserta Didik Kondisi Awal dan Siklus I

\begin{tabular}{lcc}
\hline \multicolumn{1}{c}{ Hasil Belajar } & Kondisi Awal & Siklus I \\
\hline $\begin{array}{l}\text { Belum Tuntas } \\
(<\mathrm{KKM})\end{array}$ & $55 \%$ & $37,93 \%$ \\
Tuntas (=/>KKM) & $45 \%$ & $62,07 \%$ \\
Nilai tertinggi & 77 & 90 \\
Nilai terendah & 35 & 45 \\
Nilai rata-rata & 57,33 & 68,62 \\
Jumlah Nilai $\geq 70$ & 12 & 18 \\
Persentase & $41,38 \%$ & $62,07 \%$ \\
ketuntasan &
\end{tabular}

Berdasarkan Tabel 4 dapat dilihat bahwa hasil belajar peserta didik kelas X IPS 3 pada siklus I menunjukkan ratarata nilai 69 dari 29 peserta didik. Jumlah peserta didik yang masuk kategori tuntas ada 18 orang dengan nilai $\geq 70$. Persentase peserta didik yang telah mencapai KKM sebesar 62,07\%. Nilai tertinggi yang diperoleh peserta didik adalah 90 dan nilai terendah yang diperoleh peserta didik adalah 45 .

Dibandingkan dengan hasil belajar peserta didik pada kondisi awal dengan kondisi siklus I ini mengalami peningkatan 20,69\%. Kalau kita lihat pada tabel 2 menunjukkan bahwa hasil belajar peserta didik mengalami peningkatan setelah dilakukan tindakan. Persentase peserta didik yang belum tuntas mengalami penurunan dari kondisi awal ke siklus I (dari 55\% menjadi 37,93\%). Persentase peserta didik yang sudah tuntas mengalami kenaikan dari kondisi awal ke siklus I dari $41,38 \%$ menjadi $62,07 \%$.

Indikator keberhasilan dari PTK ini adalah, PTK dikatakan sudah berhasil jika persentase peserta didik yang nilai hasil belajarnya sudah tuntas mencapai minimal 75\%. Dari tabel 2 menunjukkan bahwa persentase peserta didik yang nilainya tuntas baru mencapai $62,07 \%$, maka PTK harus dilanjutkan pada siklus II.

Dari hasil pelaksanaan penelitian siklus I selama tiga pertemuan, dapat dirangkum hal-hal yang perlu diperhatikan saat pelaksanaan pembelajaran dengan menggunakan pembelajaran kooperatif tipe Make A Match, yaitu: 1) Jika guru tidak memberikan instruksi secara jelas, banyak peserta didik yang bingung dengan langkah-langkah yang dilakukan dalam pembelajaran. 2) Guru harus dapat mengkondisikan kelas dengan baik, karena jika tidak kelas menjadi tidak kondusif pada saat permainan mencari pasangan kartu. 3) Sebelum pelaksanaan, guru harus memperkirakan durasi waktu pelaksanaan pada tiap tahapan pembelajaran agar semua yang ditargetkan dapat terlaksana. 4) Guru berperan besar dalam membimbing peserta didik dalam tiap tahapan pembelajaran, karena jika guru tidak membimbing pembelajaran tidak dapat berlangsung dengan baik. 5) Saat pelaksanaan presentasi, peserta didik yang menurut pasangannya lebih pandai selalu diandalkan untuk menyampaikan materi ataupun menjawab pertanyaan dari peserta didik lain.

Berdasarkan hasil refleksi selama pelaksanaan siklus I menggunakan pembelajaran kooperatif tipe Make $A$ Match dapat dilihat bahwa kriteria keberhasilan penelitian belum tercapai 
sesuai yang telah ditetapkan. Perlu dilakukan siklus selanjutnya untuk memperbaiki hasil pada aspek keaktifan dan hasil belajar peserta didik agar sesuai dengan yang diharapkan.

\section{Siklus II}

Rencana tindakan pada siklus II untuk memperbaiki keaktifan dan hasil belajar peserta didik dibuat Rencana Pelaksanaan Pembelajaran (RPP) untuk tiga kali pertemuan. RPP dikembangkan dengan menggunakan model pembelajaran kooperatif tipe Make A Match (Membuat Pasangan) sama dengan pada siklus I dengan penyempurnaan. Kompetensi Dasar yang diajarkan dalam RPP ini adalah KD 3.7 sub tema Badan Usaha Milik Swasta (BUMS). RPP ini akan diimplementasikan pada pertemuan pertama, kedua dan ketiga, yakni pertemuan pertama hari Senin, 3 Februari 2020, pertemuan kedua pada hari Kamis, 6 Februari 2020, pertemuan ketiga pada hari Kamis, 10 Februari 2020.

Secara umum langkah-langkah pembelajaran pada siklus II ini sama dengan pada siklus I. Perbedaanya adalah pada tindakan pada setiap langkah dioptimalkan sesuai hasil refleksi pada siklus I.

Pelaksanaan pembelajaran pada siklus II secara keseluruhan berjalan sesuai dengan perencanaan.

Tabel 5. Rekapitulasi Data Keaktifan Peserta didik pada Siklus II

\begin{tabular}{|c|c|c|c|c|c|}
\hline \multirow{2}{*}{ No } & \multirow{2}{*}{ Aspek yangdiamati } & \multicolumn{3}{|c|}{ Siklus II } & \\
\hline & & Pertemuan 1 & Pertemuan 2 & Pertemuan 3 & 3 Rata-rata \\
\hline 1 & $\begin{array}{l}\text { Memperhatikan } \\
\text { penjelasan guru }\end{array}$ & $82,76 \%$ & $86,21 \%$ & $87,93 \%$ & $85,63 \%$ \\
\hline 2 & $\begin{array}{l}\text { Mencatat materi } \\
\text { pelajaran }\end{array}$ & $93,10 \%$ & $98,21 \%$ & $94,82 \%$ & $95,37 \%$ \\
\hline 3 & $\begin{array}{l}\text { Mengajukan } \\
\text { pertanyaan }\end{array}$ & $63,79 \%$ & $65,52 \%$ & $68,97 \%$ & $66,09 \%$ \\
\hline 4 & $\begin{array}{l}\text { Menjawab } \\
\text { pertanyaan } \\
\text { atau memberi }\end{array}$ & $55,17 \%$ & $58,62 \%$ & $62,07 \%$ & $58,62 \%$ \\
\hline 5 & $\begin{array}{l}\text { Berinteraksi } \\
\text { dengan } \\
\text { peserta didik lain } \\
\text { saat mencari } \\
\text { pasangan kartu }\end{array}$ & $84.48 \%$ & $87,93 \%$ & $89,66 \%$ & $87,36 \%$ \\
\hline 6 & $\begin{array}{l}\text { Menjelaskan } \\
\text { materi pada saat } \\
\text { presentasi }\end{array}$ & $60,34 \%$ & $67,24 \%$ & $68,97 \%$ & $65,52 \%$ \\
\hline 7 & $\begin{array}{l}\text { Memperhatikan } \\
\text { penjelasan peserta } \\
\text { didik lain } \\
\text { saat presentasi }\end{array}$ & $51,72 \%$ & $56,90 \%$ & $65,52 \%$ & $58,05 \%$ \\
\hline & Rata-rata & $70,20 \%$ & $74,37 \%$ & $76,68 \%$ & $73,80 \%$ \\
\hline
\end{tabular}

Dari hasil observasi, nilai rata-rata keaktifan peserta didik pada pertemuan 1 siklus II yaitu 70,20\%, pada pertemuan 2 siklus II yaitu $74,37 \%$ dan pertemuan III sebesar 76,68\%. Dari Tabel 5 ditunjukkan bahwa terdapat peningkatan keaktifan peserta didik dari pertemuan pertama sampai pertemuan ketiga pada siklus II. Pada akhir pertemuan ketiga dilaksanakan post-test untuk mengukur pencapaian hasil belajar Peserta didik, pada materi mendeskripsikan BUMS, menentukan ciri-ciri BUMS Bentuk-bentuk BUMS, Pengertian perusahaan perseroan/firma/CV/PT, kelebihan dan kekurangan perusahaan perseorangan, firma/CV/PT, contoh BUMS, ciri-ciri perusahaan perseroan/firma/CV/PT, dan tahaptahap pendirian BUMS.

Tabel 6. Data Nilai Post-Test Peserta Didik pada Siklus II.

\begin{tabular}{lcll}
\cline { 1 - 2 } \multicolumn{1}{c}{ Keterangan } & Nilai & & Da \\
\cline { 1 - 2 } Nilai Maksimal & 95 & & ri \\
Nilai Minimal & 55 & & Tabel \\
Rata-rata & 78,10 & & 6 \\
Jumlah Nilai $\geq 70$ & 25 & & dapat \\
Persentase & $86,21 \%$ & diliha \\
ketuntasan & & &
\end{tabular}

$\mathrm{t}$ bahwa hasil belajar peserta didik kelas $X$ IPS 3 pada siklus II menunjukkan nilai rata-rata 78,10, dari 29 peserta didik. Jumlah peserta didik yang masuk kategori tuntas ada 25 orang dengan nilai $\geq 75$. Persentase peserta didik yang telah mencapai KKM sebesar $86,21 \%$. Nilai tertinggi yang diperoleh peserta didik adalah 95 dan nilai terendah yang diperoleh peserta didik adalah 55.

Dari pelaksanaan pembelajaran dengan menggunakan pembelajaran kooperatif tipe Make A Match dapat ditunjukkan bahwa terdapat peningkatan keaktifan dan hasil belajar siswa. Rata-rata keaktifan peserta didik sebesar $77,02 \%$ dimana telah melampaui kriteria keberhasilan penelitian yaitu sebesar 75\%. Persentase peserta didik yang telah 
tuntas KKM yaitu 86,21\% juga telah mencapai kriteria keberhasilan penelitian yaitu 75\%. Hal ini menunjukkan bahwa semua aspek telah mencapai keberhasilan penelitian sehingga penelitian dapat dihentikan pada siklus II.

\section{Pembahasan}

Penelitian Tindakan Kelas ini dilaksanakan di kelas X IPS 3 MAN 2 Bantul. Setelah dilakukan penelitian terhadap peserta didik kelas X IPS 3 $\begin{array}{lllll}\text { MAN } 2 & \text { Bantul pada KD } 3.7\end{array}$ Mendeskripsikan konsep badan usaha dalam perekonomian Indonesia dan KD 4.7 Menyajikan peran, fungsi dan kegiatan badan usaha dalam perekonomian Indonesia, maka dapat diketahui adanya peningkatan keaktifan dan hasil belajar peserta didik dengan penerapan pembelajaran kooperatif tipe Make AMatch. Pada siklus I, persentase rata-rata keaktifan peserta didik kategori rendah sebesar $37,36 \%$, kategori sedang $35,63 \%$ dan kategori tinggi sebesar $27,01 \%$. Pada siklus II, dengan adanya perbaikan pembelajaran dapat berjalan dengan lebih baik dan optimal. Untuk lebih jelasnya, berikut data hasil rekapitulasi rata-rata persentase keaktifan peserta didik pada siklus I dan siklus II dapat dilihat pada tabel 7.

Tabel 7 Rekapitulasi Indikator

Keberhasilan Keaktifan Belajar

\begin{tabular}{|c|c|c|c|c|}
\hline No & Kategori & Siklus I & $\begin{array}{l}\text { Siklus } \\
\text { II }\end{array}$ & $\begin{array}{l}\text { Peningkat } \\
\text { an/penuru } \\
\text { nan }\end{array}$ \\
\hline 1 & Tinggi & $\begin{array}{c}27,01 \\
\%\end{array}$ & $\begin{array}{c}45,97 \\
\%\end{array}$ & $18,96 \%$ \\
\hline 2 & Sedang & $\begin{array}{c}35,63 \\
\%\end{array}$ & $\begin{array}{c}31,61 \\
\%\end{array}$ & $(4,02 \%)$ \\
\hline 3 & Rendah & $\begin{array}{c}37,36 \\
\%\end{array}$ & $\begin{array}{c}22,41 \\
\%\end{array}$ & $(14,95 \%)$ \\
\hline
\end{tabular}

Persentase rata-rata keaktifan peserta didik kategori rendah pada siklus II sebesar 22,41\%, kategori sedang 31,61\% dan kategori tinggi sebesar $\quad 45,97 \%$. Penurunan persentase keaktifan peserta didik kategori rendah dari siklus I ke siklus II sebesar 14,95\%.

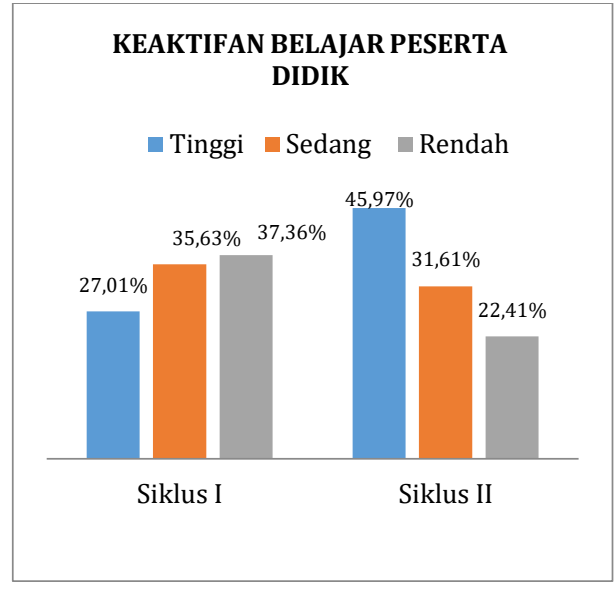

Grafik 1. Kategori Keaktifan Belajar Peserta didik Siklus I dan Siklus II

Terdapat peningkatan kategori minimal sedang dari siklus I ke siklus II sebesar 14,94\%. Hal tersebut dikarenakan peran guru dalam memotivasi dan memberikan arahan kepada peserta didik bahwa materi yang disampaikan akan bermanfaat bagi peserta didik, serta kesadaran peserta didik bahwa dengan memperhatikan materi yang disampaikan oleh guru maka mereka akan lebih lancar pada saat permainan mencari pasangan kartu maupun pada saat mengerjakan soal post-test.

Berdasarkan hasil penelitian yang telah dilakukan dan merujuk pada teori Paul D. Dierich dalam Hamalik tentang pembagian aspek keaktifan belajar peserta didik dan kaitannya dengan berbagai aktivitas yang dilakukan pada pembelajaran kooperatif tipe Make $A$ Match, dapat disimpulkan bahwa pembelajaran kooperatif tipe Make A Match dapat meningkatkan keaktifan peserta didikselama proses pembelajaran(Huda, 2015).Hal ini sejalan dengan yang disampaikan oleh Miftahul Huda bahwa pembelajaran kooperatif tipe Make AMatch dapat meningkatkan aktivitas belajar peserta didik baik secara kognitif maupun psikomotor (Huda, 2015).

Hasil penelitian yang telah dilakukan terhadap peserta didik kelas X IPS 3 MAN 2 Bantul dengan menggunakan 
pembelajaran kooperatif tipe Make AMatch mampu meningkatkan hasil belajar peserta didik mata pelajaran ekonomi KD 3.7 Mendeskripsikan konsep badan usaha dalam perekonomian Indonesia dan KD 4.7 Menyajikan peran, fungsi dan kegiatan badan usaha dalam perekonomian Indonesia. Hal tersebut dapat dilihat dengan adanya peningkatan hasil belajar peserta didik dari pra siklus, siklus I, dan siklus II. Data rincian hasil belajar peserta didik dapat dilihat pada tabel dan grafik di bawah ini.

Tabel 8 Data Hasil Belajar Peserta Didik

\begin{tabular}{lccc}
\hline $\begin{array}{c}\text { Hasil Belajar } \\
\text { Siswa }\end{array}$ & $\begin{array}{c}\text { Kondisi } \\
\text { Awal }\end{array}$ & Siklus I & Siklus II \\
\hline Nilai tertinggi & 77 & 90 & 95 \\
$\begin{array}{l}\text { Nilai terendah } \\
\text { Nilai rata-rata }\end{array}$ & 35 & 45 & 55 \\
$\begin{array}{l}\text { Jumlah peserta } \\
\text { didik tuntas }\end{array}$ & 12 & 68,62 & 78,10 \\
$\begin{array}{l}\text { Persentase } \\
\text { ketuntasan }\end{array}$ & $41,38 \%$ & $62,07 \%$ & $86,21 \%$ \\
$\begin{array}{l}\text { Persentase } \\
\text { belum tuntas }\end{array}$ & $58,62 \%$ & $37,93 \%$ & $13,79 \%$ \\
\hline
\end{tabular}



Grafik 2. Peningkatan Hasil Belajar Peserta Didik

Berdasarkan Tabel 8 dan Grafik 2 dapat diketahui bahwa nilai rata-rata kelas pada kondisi awal yaitu 57 dengan jumlah peserta didik yang nilainya memenuhi KKM sebanyak 12 orang dan persentase ketuntasan 41,38\%. Pada siklus I, nilai rata-rata kelas mengalami kenaikan menjadi 68,62 dengan 18 peserta didik memenuhi KKM dan 11 peserta didik tidak memenuhi KKM dimana persentase ketuntasan sebesar
$62,07 \%$. Hasil belajar pada siklus I tersebut belum memenuhi kriteria keberhasilan sehingga dilanjutkan pada siklus II. Pada siklus II, nilai rata-rata kelas kembali meningkat menjadi 78,10 dengan terdapat 25 peserta didik memenuhi KKM dan persentase ketuntasan 86,21\%. Hanya terdapat 4 peserta didik yang tidak memenuhi KKM, sehingga hasil belajar pada siklus II sudah memenuhi kriteria keberhasilan penelitian.

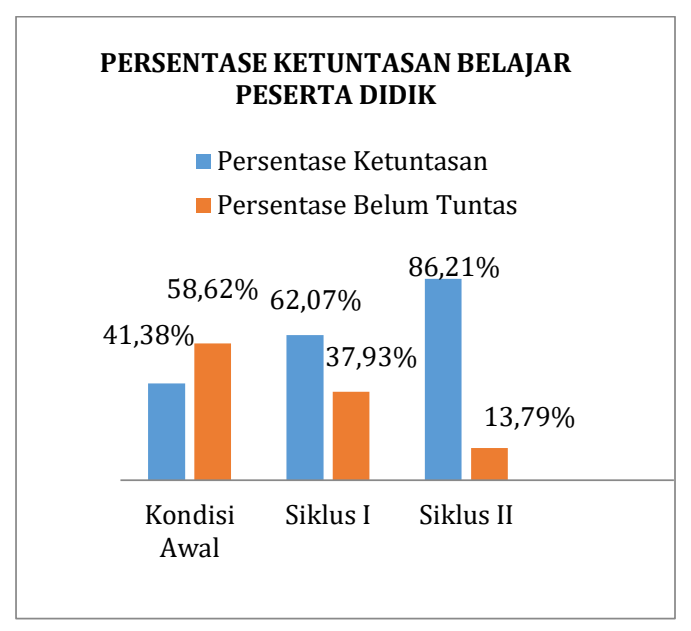

Grafik 3. Persentase Ketuntasan Belajar Peserta Didik

Berdasarkan Grafik 3 diatas menunjukkan bahwa pada siklus dua sudah mencapai indikator ketercapaian yang menetapkan minimal sebesar $75 \%$ nilai peserta didik tuntas. Kenaikan hasil belajar peserta didik dipengaruhi oleh beberapa faktor, diantaranya, pada saat kegiatan pembelajaran pada siklus II peserta didik sudah terbiasa dengan pembelajaran kooperatif tipe Make AMatch sehingga pada saat guru menyampaikan materi peserta didik lebih memperhatikan dan mau mencatat materi karena akan digunakan dalam permainan dan post-test. Peserta didik juga semakin aktif bertanya jika ada hal yang belum mereka pahami. Saat presentasi pasangan, peserta didik juga sudah memiliki kesadaran untuk memperhatikan peserta didik lain yang sedang presentasi dan aktif dalam mengoreksi kesesuaian antara kartu 
pertanyaan dan kartu jawaban milik peserta didik lain.

Berdasarkan hasil penelitian dan didukung oleh penelitian yang relevan dapat diketahui bahwa dengan penerapan pembelajaran kooperatif tipe Make AMatch pada mata pelajaran ekonomi KD $3.7 \quad$ Mendeskripsikan konsep badan usaha dalam perekonomian Indonesia dan KD 4.7 Menyajikan peran, fungsi dan kegiatan badan usaha dalam perekonomian Indonesia, dapat meningkatkan hasil belajar peserta didik kelas X IPS 3 MAN 2 Bantul.

\section{PENUTUP}

\section{Simpulan}

Simpulan penelitian ini sebagai berikut. a) Pelaksanaan pembelajaran ekonomi di kelas X IPS 3 MAN 2 Bantul dengan menggunakan model pembelajaran Kooperatif Tipe Make A Match dapat meningkatkan keaktifan belajar peserta didik. Hal ini terlihat pada siklus I ratarata keaktifan peserta didik sebesar $55,91 \%$. Kemudian pada siklus II ratarata keaktifan peserta didik meningkat menjadi $73,80 \%$. Sehingga dapat dikatakan bahwa keaktifan peserta didik meningkat setelah dilakukan perbaikan proses pembelajaran pada siklus II sebesar 17,89\%. b) Pelaksanaan pembelajaran ekonomi di kelas X IPS 3 MAN 2 Bantul dengan menggunakan model pembelajaran Kooperatif Tipe Make A Match dapat meningkatkan hasil belajar peserta didik. Hal ini berdasarkan hasil post-test pada siklus I persentase peserta didik yang tuntas KKM sebesar $62,07 \%$ kemudian meningkat menjadi $86,21 \%$ pada siklus II. Nilai rata-rata kelas juga meningkat dari siklus I sebesar 68,62 meningkat menjadi 78,10 pada siklus II.

\section{Saran}

Berikut disampaikan beberapa saran a) Bagi Guru: a) Guru dapat menerapkan pembelajaran kooperatif tipe make a match pada materi lain sebagai variasi pelaksanaan pembelajaran di kelas agar peserta didik tidak jenuh atau bosan, b) Guru harus mampu mengatur waktu dengan optimal pada saat pelaksanaan pembelajaran dengan make a match agar semua kegiatan dapat terlaksana dalam setiap pertemuannya, c) Guru dapat memberikan variasi lain dalam pembelajaran kooperatif tipe make a match agar peserta didik lebih antusias dalam mengikuti pembelajaran, seperti memberikan reward kepada pasangan paling cepat dan paling tepat dalam mencari pasangan kartu. 2) Bagi Peseta Didik: a) Sebaiknya peserta didik membiasakan diri untuk memperhatikan materi pelajaran dan aktif bertanya jika ada materi yang tidak dipahami, b) Sebaiknya peserta didik juga mencari materi referensi lain agar tidak hanya menerima materi dari guru sehingga guru maupun peserta didik dapat terlibat aktif dalam pembelajaran. 3) Bagi madrasah diharapkan dapat memberikan dukungan kepada guru agar lebih banyak menerapkan berbagai variasi metode pembelajaran di dalam kelas. 4) Bagi Peneliti Lain, penelitian ini diharapkan dapat dikembangkan untuk penelitian selanjutnya agar dapat terus mengembangkan proses pembelajaran yang ada. 


\section{DAFTAR PUSTAKA}

Dimyati dan Mudjiono.( 2015). Belajar dan Pembelajaran. Jakarta : Rineka Cipta

Hamdan, T.A., \& Khader, F.(2015).Alignment of Intended Learning Outcomes with Quellmalz Taxonomy and Assesment Practices in Earley Childhood Education Courses. International Journal of Humanities and Social Science, 5(3).

Hamzah. B Uno \& Nurudin Muhammad. (2013). Belajar dengan Pendekatan PAILKEM: Pembelajaran Aktif, Inovatif, Lingkungan, Kreatif, Efektif,Menarik. Jakarta: Bumi Aksara.

Huda, Miftahul. (2015). Model-Model Pengajaran Dan Pembelajaran.Yogyakarta: Pustaka Pelajar.

Kpolovie, James P., Igho JOE, A., \& Okoto, T. (2014). Academic Achievement Prediction: Role of Interest in Learning and Attitude towards School. International Journal of Humanities Social Sciences and Education, 1(11), 73-100. www.arcjournals.org

Lasmini, L. (2017). Penerapan Teknik Make A Match untuk Meningkatkan Hasil Belajar Materi Perbandingan dan Skala pada Siswa Kelas VI SD. Brilliant: Jurnal Riset Dan Konseptual, 2(3), 260. https://doi.org/10.28926/briliant.v2i3.68

Maharani, O. D. tri, \& Kristin, F. (2017). Peningkatan Keaktifan dan Hasil Belajar IPS Melalui Model Pembelajaran Kooperatif Tipe Make A Match. Wacana Akademika: Majalah Ilmiah Kependidikan, 1(1), 1-12. https://doi.org/10.30738/wa.v1i1.998

Pratiwi, R. H. (2018). Metode Pembelajaran "Make A Match" Dan Pengaruhnya Terhadap Hasil Belajar IPA. Florea: Jurnal Biologi Dan Pembelajarannya, 5(1), 37. https://doi.org/10.25273/florea.v5i1.2291

Putri Z, Rahmi, Jufrida, \& Darmaji. (2017). Problem Based Instruction ( PBI ). Jurnal Edu Fisica, 6(1), 1147-1156. file:///Users/Kuo/Documents/Papers/Maloney/Maloney 2011 Reviews in PER.pdf\% $5 \mathrm{~cm}$ Papers2://publication/uuid/2C4DE054-3B80-4BC6-A24D475846AB8452\%0Ahttp://aapt.scitation.org/doi/10.1119/1.1763175

Putri, Alia D. H. (2018). Penerapan Model Pembelajaran Kooperatif Tipe Make A Match Berbantuan Kartu Bergambar Untuk Meningkatkan Hasil Belajar Siswa. Jurnal Bidang Pendidikan Dasar, 2(1A), 70-77. https://doi.org/10.21067/ibpd.v2i1a.2351

Rusman, dkk. 2011. Pembelajaran berbasis teknologi informasi dan komunikasi, mengembangkan profesionalitas guru. Jakarta: PT. RajaGrafindo Rusman. (2018). Belajar dan Pembelajaran Berorientasi Standar Proses Pendidikan. Jakarta: Prenada Media Group.

Rusman. (2018). Model-Model Pembelajaran. Depok: Rajawali Pers.

Samsur. (2018). Penerapan Model Pembelajaran Kooperatif Tipe Make A Match Untuk Menigkatkan Hasil Belajar IPS Siswa Kelas V Sekolah Dasar. Samsur samsurmursinah @ gmail .com SD Negeri 54 Sebangar Kecamatan Mandau Kabupaten Bengkalis Pendidikan IPS sekolah m. 7(April), 170-177.

Sanjaya, Wina (2013). Strategi Pembelajaran Berorientasi Standar ProsesPendidikan. Jakarta: Kencana Prenada Media Group.

Sudjana, N. (2017). Penilaian Hasil Proses Belajar Mengajar. Remaja Rosdakarya. 